\title{
DRUG TOLERANCE/INTOLERANCE IN DOMESTIC DOG (Canis lupus familiaris) WITH MDR1 GENE DEFECT
}

\section{TOLERANCJA/NIETOLERANCJA NA LEKI U PSA DOMOWEGO (Canis lupus familiaris) Z DEFEKTEM GENU MDR1}

Department of Genetics and Animal Breeding, Warsaw University of Life Sciences, Poland ${ }^{1}$ Department of Large Animal Diseases with Clinic, Warsaw University of Life Sciences, Poland

\begin{abstract}
Streszczenie. Iwermektyna to lek stosowany na szeroką skalę w zwalczaniu pasożytów wewnętrznych i zewnętrznych zwierząt. Jest to związek bezpieczny dla ssaków. Mechanizm jego działania opiera się na zaburzeniu przewodzenia impulsów nerwowych. Glikoproteina $P$ jest błonowym białkiem transportowym obecnym w komórkach endotelialnych wielu narządów, takich jak płuca, nerki, wątroba, trzustka itd. Hamuje ono przedostawanie się toksyn do komórek nerwowych mózgu i ich penetrację. Pełni też swoją funkcję wobec innych narządów, poza układem nerwowym; są to np. bariery: krew-jądro, krew-łożysko, krew-mocz. Białko to jest kodowane przez gen MDR1 (ang. Multidrug Resistance Gene) i znajduje się w błonach komórkowych bariery krew-mózg. W przypadku wystąpienia mutacji genu MDR1 białko powstałe na podstawie zmienionej informacji genetycznej nie jest zdolne do pełnienia swoich funkcji. W takim przypadku iwermektyna przedostaje się do komórek ośrodkowego układu nerwowego psów i wywołuje objawy neurotoksyczne, dlatego ważna jest wcześniejsza diagnostyka, a także szybkie działanie w celu zapobieżenia wystąpieniu objawów zatrucia. W artykule przedstawiono przyczyny oraz skutki wystapienia mutacji, a także elementy diagnostyki molekularnej pozwalającej na identyfikację mutacji. Sporządzono również listę leków, które mogą wywoływać objawy neurotoksyczne u psów z mutacją genu MDR1.
\end{abstract}

Key words: ivermectin, transport proteins, MDR1 gene.

Słowa kluczowe: iwermektyna, białka transportowe, gen MDR1.

\section{INTRODUCTION}

MDR1 gene mutation (Multi Drug Resistance) in domestic dog (Canis lupus familiaris) leads to hypersensitivity to certain antiparasitic drugs, including the popular ivermectin. Ivermectin (a macrocyclic lactone), used in small animal practice at regular base, paralyses the muscles of parasites, and in most dogs it remains perfectly safe. However, in case of hypersensitivity, ivermectin is highly toxic to cells in the peripheral nervous system.

Corresponding author - Adres do korespondencji: Joanna Gruszczyńska, Department of Genetics and Animal Breeding, Warsaw University of Life Sciences, Ciszewskiego 8, 02-786 Warszawa, Poland, e-mail: joanna_gruszczynska@sggw.pl 
Therefore, both veterinary surgeons and owners should be aware of this phenomenon and its possible fatal consequences. Up to date many polymorphic alleles of MDR1 gene have been identified (Han et. al. 2010; Mizukami et al. 2012; Mizukami et al. 2013; Monobe et al. 2015), yet the most important mutation remains the one which leads to a loss of four base pairs in 227-230 nucleotide, known as MDR1 (c.227-230del) or ABCB1-1ه (Mizukami et al. 2012).

Domestic dogs can be either free of the mutation (MDR1+/+), or carry one (heterozygote MDR1+/-) or two mutated allele (homozygote MDR1-/-). Researches prove that MDR1 gene mutation (c.227-230del) is common in collies (rough and smooth), with frequencies as high as $54 \%$ in the USA (Mealey and Meurs 2008), 59\% in Germany (Gramer et al. 2011) and $64 \%$ in France (Hugnet et al. 2004). The mutation occurs also in some breeds related to collies, i.e. the Shetland Sheepdog, the Australian Shepherd (American type) and the Border Collie; also in breeds less popular in Poland - the Old English Sheepdog and the Longhaired Whippet. Occasionally, the mutation is also found in the White Swiss Shepherd (Geyer 2005) and in German Shepherd, mainly in the USA.

MDR1 gene mutation results in glycoprotein $\mathrm{P}$ ( $\mathrm{P}-\mathrm{gp}$, an important membrane protein) malfunctioning. P-pg is involved in proper transport of different substances, including drugs, and prevents their penetration into nervous cells. Apart from ivermectin, several other drugs have neurotoxic properties, e.g. doramectin, moxidectin and loperamide. MDR1 mutation is found with similar frequencies in different areas, therefore it can be assumed to come from a common ancestor; pedigree studies locate it some before the year 1800 in Great Britain (Taylor 2011). Currently the mutation is easy to identify and early diagnosis allows relevant measures to prevent the occurrence of neurotoxicity. Most diagnostic test are based on PCR reaction and several laboratories in Europe and North America offer diagnostic kits and results within just over a dozen days.

The aim of this article was to present a list of drugs that cause neurotoxic symptoms in dogs with the MDR1 defect, which will help veterinarians recommend suitable deworming products and other drugs, especially in the case of dogs belonging to the aforementioned races, in which the mutation MDR1 was detected.

\section{DRUGS WHICH MAY BE NEUROTOXIC TO ANIMALS WITH MDR1 DEFECT NEUROTOXICITY IN DOGS}

Any drug, introduced into the body, is introduced in the relevant metabolic pathway with its enzyme system. Consequently, any inhibition of enzyme activity leads to impairments of drug absorption/metabolism. This inhibition can be determined genetically and leads to "congenital metabolic defect" (Roliński 2008). Most veterinary drugs act on the body by chemical means, defined by their specific molecular structure. According to the theory of receptors, drugs are bound with highly specific membrane receptors or - in case of hormones - with intracellular ones (Roliński 2008).

Dogs can absorb potentially dangereous substances through oral or topical exposures as well as via injection. Symptoms arise when the drug is present in the body at high enough concentrations that it crosses the blood-brain barrier and adversely affects neurologic function. Typical signs include: dilated pupils, unsteadiness when walking, mental dullness, drooling, vomiting, blindness, tremors, seizures, coma. 
Treatment is essentially symptomatic and supportive. If the poisoning is caught early enough, decontamination is helpful (e.g., washing dogs after topical exposure or inducing vomiting and/or activated charcoal administration within a few hours of ingestion). Intravenous fluid therapy, endotracheal intubation, mechanical ventilation, extensive nursing care, seizure control, application of eye lubricants if the patient cannot blink, and nutritional support may all also be necessary. In some cases, intravenous lipid emulsion therapy, which is a new but promising option for certain types of poisoning, might be worth considering.

prognosis can be quite good if aggressive treatment is initiated in a timely manner. Severe cases of overdose often require several weeks of therapy, the expense is often prohibitive.

Currently there are over 20 drugs classified as glycoprotein P substrates (Robertson et al. 2004). They can be divided into three major groups: drugs used in cancer treatments (antineoplastic), gastroenterological drugs and antiparasitic ones.

\section{ANTIPARASITIC DRUGS AND THEIR MODE OF ACTION}

Currently, veterinary medicine employs a wide range of drugs against endo- and ectoparasites, both in treatment and in prophylaxis. The most common drugs are benzimidazoles, imidazotiazoles, tetrahydropirimidines, piperazines, phosphoorganics and macrocyclic lactones, the latter isolated from Streptomyces bacteria and showing a wide spectrum of activity against both endo- and ectoparasites (Turner and Schaeffer 1989). Lactones are effective in treatment of adult and larval forms of gastrointestinal and lung roundworms, ticks, lice, mites and gadfly larvae; they are not effective against tapeworms and flukes. They act on nematodes and arthropods by paralyzing their muscles in result of activation of GABA-ergic system and subsequent opening of cellular membrane channels, followed by influx of chloride ions, which in turn leads to hyperpolarization and abnormal nerve conduction (Wolstenholme and Rogers 2005). Additionally, macrocyclic lactones affect GABA receptors; in mammals GABA act as neurotransmitters in inhibition of nerve signals in central nervous system and performs the same function in peripheral neurons of both nematodes and arthropods. Due to the presence of blood-brain barrier, mammals have good tolerance to these substances, whereas they are toxic to invertebrate parasites. However, in case of overdose, mammals can also develop ataxia, tremor, vomiting, coma and eventual death. Same symptoms occur in animals with MDR1-related hypersensitivity (Lespine et al. 2007).

\section{ANTIPARASITIC DRUGS}

Ivermectin - highly lipophilic drug, easily absorbed both after oral and subcutaneous administration. It is commonly used as a heartworm preventative in dogs and for the treatment of certain types of external (e.g., mites) and internal parasites. Bioavailability in both cases reaches up to $100 \%$ and its maximal plasma concentration comes after 3-8 hours; up to $98 \%$ is excreted in faeces. Dosage in dog: $0.006-0.012 \mathrm{mg} / \mathrm{kg}$ of body mass. Neurotoxic symptoms appear after oral administration of $100 \mu \mathrm{g} / \mathrm{kg}$ (Geyer et al. 2012).

Selamectin - chemically modified precursor of avermectin, is recommended for use in dogs six weeks of age or older. 
This drug is used against fleas in dogs and cats, in treatment of ear mites and mange, and also against intestinal roundworms in dogs. It accumulates in sebaceous glands which become a natural reservoir of the active drug. Applied directly onto skin (Michael et al. 2001).

Moxidectin - chemically modified derivative of nemadectin, similar to ivermectin in its therapeutic properties, yet more lipophilic and thus staying longer in tissues. It prevens and controls heartworms and intestinal worms, disrupting their nerve transmissions and resulting in paralysis and death of the parasites. Administered orally in prophylaxis. Symptoms of intoxication appear after oral administration of $400 \mathrm{mg} / \mathrm{kg}$ (Snowden et al. 2006). Moxidectin (parasiticide) is often combined with Imidacloprid, the other active ingredient which is insecticide and attacks the flea's nervous system to cause paralysis and death.

Doramectin - modified product of Streptomyces bacteriae, with wide spectrum typical of other avermectins. It is indicated for the treatment and control of gastrointestinal roundworms, lungworms, eyeworms, grubs, sucking lice and mange mites. The injectable form has shown useful in treating various nematode and arthropod parasites in dogs. Absorbed slowly - the maximum blood concentration is reached after 5 days and maintained at active levels for up to 4 weeks. Sold as $15 \%$ solution in sesame oil. Symptoms of intoxication appear after administration of $100 \mathrm{mg} / \mathrm{kg}$ of body mass (Yas-Natan et al. 2003).

Abamectin - used against adult and larval forms of gastrointestinal and lung nematodes, also against lice and scabies, sold in $2 \%$ solution; it is more toxic than ivermectin. Abamectin is effective against heartworm larvae in the blood.Three- or four times overdose, i.e. exceeding $40 \mathrm{mg} / \mathrm{kg}$ of body mass (Parton 2009) leads to neurotoxic symptoms, including apathy and ataxia.

Milbemicin oxime - after oral administration up to $90 \%$ of the drug is excreted with faeces. Used in prophylaxis against ectoparasites and gastrointestinal nematodes; a $0.5 \mathrm{mg} / \mathrm{kg}$ dose protects against Dirofilaria immitis invasion for 30-45 days. It is used orally to control hookworm, roundworm and certain whipworm infections in dogs. Toxic when the dose exceeds the recommended one by 10 times (Mccall et. al. 1996).

\section{ANTINEOPLASTIC DRUGS}

Vincristine - cytostatic, phase-specific alkaloid, in veterinary medicine administered intravenously. Used in treatment of acute lymphoblastic leukemia, Hodgkin's disease, lymphomas, sarcomas, canine transmissible veneral tumor and lung cancer. Highly neurotoxic when overdosed (Mealey et al. 2008).

Doxorubicine - semi-synthetic drug used in cancer treatment, including hematopoietic malignancies and sarcomas, administered intravenously. Typical symptoms of intoxication are cardiomyopathy and typhlitis (Tabe et al. 2006).

Vinblastine - cytostatic alkaloid that inhibits mitosis through tubuline binding, used in treatment of Hodgkin's disease, bladder- and testicular carcinoma. Administered intravenously, may lead to different neuropathies (Chen et al. 2000).

\section{GASTROENTOROLOGICAL DRUGS}

Loperamide - petidine derived, antidiarrheal drug in form of tablets or as a solution. Acts on intestinal opioid receptors, inhibits intestinal motorics and excretion.It decreases intestinal motility and reduces secretions caused by certain factors such as toxins. Recommended dosage in dogs: $0.04 \mathrm{mg} / \mathrm{kg} 4$ times a day (Sator et al. 2004). 
Domperidone - enchances tension and peristaltic of gaster (upper stomach) and duodenum motorics. It is an antiemetic drug which exerts its effects through anti-dopaminergic activity, with efficacy similar to ondansetron and superior to metoclopramide. This drug has also been used successfully in the clinical resolution of symptoms associated with visceral leishmaniasis.

Domperidone regulates the motility of gastric and small-intestinal smooth muscle and has some effect on esophageal motility. Cannot penetrate an unbroken blood/brain barrier. Used in drops or tablets. Recommended oral dose $0.3-0.5 \mathrm{mg} / \mathrm{kg}$ every 8 hours (Borst and Schinkel 2013).

Ondansetrone - antiemetic, antagonistic to serotonine receptors. It is used in dogs to treat a variety of conditions with the most common being vomiting. It can also be used to treat sleep-apnea and pruritus (itching). Used during chemo- and radiotherapy of cancer, also in post-surgical treatment Recommended oral dose in dogs: $0.1-0.2 \mathrm{mg} / \mathrm{kg}$ (Schinkel and Wagenaar 1996). Neither registered nor used in dogs in Poland.

\section{OTHER DRUGS WHICH MAY BE NEUROTOXIC IN ANIMALS WITH MDR1 DEFECT}

Acepromazine - has a variety of uses (ex: anti-nausea, anti-emetic, decrease itching due to allergies) but is routinely used to sedate fearful or aggressive dogs prior to veterinary visits or general anaesthesia (Geyer and Janko 2012) or as an at-home remedy for noise phobias (thunderstorms, fireworks).

- butorphanol - a tranquilizer and painkiller (Geyer and Janko 2012). Butorphanol is intended for use where short and short to medium duration analgesia is required, especially in dogs for relief of moderate visceral pain and sedation in combination with certain $\alpha 2$-adrenoceptor agonists ;

- erytromycin - a strong bacteriostatic macrolide., is effective for most known bacteria that infect the skin, bones or sinuses. The drug can also be used in the Lyme disease, caused by ticks. However, erythromycin cannot be used in intestinal infections such as the infection caused by $E$. coli. The drug cannot be administered to reduce infections caused by intestinal worms ;

- metoclopramide - an antinausea/antiemetic drug; neither registered nor used in Poland. Metoclopramide is often used as an anti-vomiting drug. In otherwise healthy dogs that have a chronic vomiting problem due to delayed gastric emptying, Metoclopramide helps reduce the delay by speeding up the passage of food.

New research on dogs with MDR1 defect and neurotoxity is being in progress and many new drugs are being tested, e.g. etoposide, mitoxantrone, paclitaxel (used in cancer therapy), chinidine (preventing arrhytmia) and rifampicin (semi-syntetic germicidal antibiotic).

There are many potentially risky drugs that may be neurotoxic. Some of them can be used in reasonable doses and under veterinary control, others are absolutely forbidden in treatments of MDR1 dogs.

Below there is a list of potentially neurotoxic drugs (http://www.laboklin.co.uk), divided into three classes depending on the degree of hazard. Class $A$ drugs are the ones with the highest risk to MDR1 dogs, class B drugs can be used only under strict supervision, and class $C$ requires strict following of recommended dosage and ways of administration. As general advice, doses should be lowered from 25\% (MDR1+/-) to 50\% (MDR1-/-) (Mealey 2012). 
Class A:

Anti-parasitic drugs: ivermectine, (Diapec $₫$, Ecomectin $₫$, Equimax $®$, Eqvalan $₫$, Ivomec $₫$, Noromectin $₫$, Paramectin $\AA$, Qualimec $®$, Sumex $®$, Virbamec $®$ ) doramectine (Dectomax $®$ ), moxidectine (Cydectin $®$, Equest $\circledast$ ).

Antiemetics: loperamide (Imodium $®$ ).

Class B:

Cytostatics: vinblastine, vincristine, doxorubicine, methotrexat (Docetaxel $\AA$, Methotrexat $\AA$, Vincristine () ).

Immunosupressants: cyclosporine (Cyclosporin $A ®)$.

Cardiac drugs: digoxine (Digoxin $®)$, methyldigoxine (Methyldigoxin $®)$.

Opioids: morphine (Morphium $\left.{ }^{\circledR}\right)$.

Antiarrhythmic drugs: verapamil (Verapamil $₫)$, diltiazem (Diltiazem $®)$, chinidine (Chinidine $\left.{ }^{\circledR}\right)$. Antiemetics: ondansetron (Zofran $®$ ), domperidon (Domperidon $®$ ), metoclopramide (Metoclopramide $($ ).

Antibiotics: sparfloxacin (Spacin $®)$, grepafloxacin (Raxar®), erythromycin (Erymax®).

Antihistamine drugs: ebastine (Evastin $®)$.

Glucocorticoides: dexamethason (Dexamethason®).

Others: acepromazine $(A C P \circledast$, Atravet $®)$, butorphanol (Torbugesic $®, B u t o m i d o r \circledR)$, etoposide (Etopophos $\AA$ ), mitoxantrone (Novantrone $®$, Mitozantrone $®$ ), ondansetron (Zofran $®$ ), paclitaxel (Taxol®), rifampicin (Rifampin $®$ ).

Class C:

Antiparasitic drugs: selamectin (Stronghold $\AA$, Revolution $®$ ), milbemycin (Milbemax $®$ ), moxidectine (Advocate $®$ ).

The most dangerous for dogs are antiparasitic drugs: ivermectine, doramectine, moxidectine, and also loperamide (antiemetic).

\section{DRUGS WHICH MAY BE SAFELY USED IN DOGS WITH MDR1 GENE MUTATION}

Among numerous glycoprotein $\mathrm{P}$ substrates there are several drugs which are not neurotoxic, even though the protein function is impaired, and they can be used in treatment of MDR1 mutation. Some safe antiparasitic drugs are listed below:

- Pyrantelum - used in treatment of pinworms, roundworms (toxocariosis) and hookworms in puppies. Rocommended dose $0.2 \mathrm{mml} / 1 \mathrm{~kg}$ and must not be exceeded.

- Droncit - used against tapeworms, roundworms and pinworms. Recommended single dosage: $25 \mathrm{mg} / \mathrm{kg}$ of body weight.

- Drontal - veterinary drug against roundworms and tapeworms, in capsules or tablets.

- Panacur - against adult forms of roundworms and tapeworms, sold in tablets.

- Advantix - prevention and treatment of tick and flea infestation, also deterring mosquitos and flies. Solution for external use.

Several other drugs can be successfully used in antiparasitic treatment. Any of them can have some undesirable side effects when used improperly, but usually these effects are not related to MDR1 defect. Individual sensitivity, allergic reactions, dose and way of administering must be taken into consideration. Some drugs, e.g. erythromycin, require extra supplements protecting gastrointestinal mucous membranes. 
In this article was presented a list of drugs that cause neurotoxic symptoms in dogs with the MDR1 defect. This list will help veterinarians recommend suitable deworming products and other drugs, especially in the case of dogs belonging to the aforementioned races, in which the mutation was described. The owners of these dogs are recommended to perform molecular diagnostic tests that can identify carriers of the mutated gene. In case the dog carries even one copy of the mutated gene MDR1, it should be excluded the dog should not be used in breeding and thus prevented from spreading the mutated gene in the population. Early detection of MDR1 mutation will customize the treatment to avoid using specific drugs. Additionally, entry in the documentation of the dog can prevent the onset of complications.

\section{CONCLUSIONS}

The aim of this article was to present a list of drugs that cause neurotoxic symptoms in dogs with the MDR1 defect, which will help veterinarians recommend suitable deworming products and other drugs, especially in the case of dogs belonging to the aforementioned races, in which the mutation was described. The owners of these dogs are recommended to perform molecular diagnostic tests that can identify carriers of the mutated gene. In case the dog carries even one copy of the mutated gene MDR1, it should be excluded the dog should not be used in breeding and thus prevented from spreading the mutated gene in the population. Early detection of MDR1 mutation will customize the treatment to avoid using specific drugs. Additionally, entry in the documentation of the dog can prevent the onset of complications.

\section{REFERENCES}

Badowska-Kozakiewicz A. 2011. Zjawisko oporności wielolekowej w nowotworach. Rola glikoproteiny P [Multidrug resistance in tumors. The role of P-glycoprotein]. Życie Weter. 86, 211-214. [in Polish]

Borst P., Schinkel A.H. 2013. P-glycoprotein ABCB1: a major player in drug handling by mammals. J. Clin. Invest. 123(10), 4131-4133.

Chen G.K., Duran G.E., Mangili A. 2000. MDR1 activation is the predominant resistance mechanism selected by vinblastine in MES-SA cells. Br. J. Cancer. 83(7), 892-898.

Choundhuri S., Klaassen C.D. 2006. Structure, function, expression, genomic organization, and single nucleotide polymorphism of human ABCB1 (MDR1), ABCC (MRP), and ABCG2 (BCRP) efflux transporters. Int. J. Toxicol. 25(4), 231-59.

Collins F.S. 1991. Cystic fibrosis: molecular biology and therapeutic implications. Science 8(5058), 774-779.

Combe I. 1987. Herding dogs. Their origins and development in Britain. London, Faber \& Faber Ltd.

Cordon-Cardo C. 1989. Multidrug-resistance gene (P-glycoprotein) is expressed by endothelial cells at blood-brain barier sites. PNAS 1, 695-698.

Cordon-Cardo C., Boccia J., Casals D. 1990. Expression of the multidrug resistance gene product (P-glycoprotein) in human normal and tumor tissues. J. Histochem. Cystochem. 38(9), 1277-1287.

Dourmishev A.L., Schwartz R.A. 2005. Ivermectin: pharmacology and application in dermatology. Int. J. Dermatol. 44(12), 981-988.

Dresser M.J., Leabman M.K. 2001. Transporters involved in the elimination of drugs in the kidney: organic anion transporters and organic cation transporters. J. Pharm. Sci. 90, 397-421. 
Geyer J., Döring B., Godoy J.R., Moritz A., Petzinger E. 2005a. Development of a PCR-based diagnostic test detecting a nt230(del4) MDR1 mutation in dogs: verification in a moxidectin-sensitive Australian Shepherd. J. Vet. Pharmacol. Ther. 28(1), 95-99.

Geyer J., Godoy J.R., Leidolf R., Moritz A. 2005b. Frequency of the nt230 (del4) MDR1 mutation in Collies and related dog breeds in Germany. J. Vet. Pharmacol. Ther. 28(6), 545-551.

Geyer J., Janko C. 2012. Treatment of MDR1 mutant dogs with macrocyclic lactones. Curr. Pharm. Biotechnol. 13(6), 969-986.

Glavinas H., Krajcsi P., Cserepes J. 2004. The role of ABC transporters in drug resistance, metabolism and toxicity. Curr. Drug. Deliv. 1, 27-42.

Hopper K., Aldrich J., Haskins S.C. 2008. Ivermectin toxicity in 17 collies. J. Vet. Med. 16, 89-94.

Hugnet K., Bentjen S.A., Mealey K.L. 2004. Frequency of the mutant MDR1 allele associated with multidrug sensitivity in a sample of collies from France. J. Vet. Pharmacol. 27(4), 227-229.

Kania B., F. 2011. Nowoczesna farmakologia weterynaryjna i terapia. Wrocław, Wydaw. Med. Farm. MedPharm Polska, 20-32. [in Polish]

Kawabata A., Momoi Y., Inoue-Muryama M., Iwasaki T. 2005. Canine mdr1 gene mutation in Japan. J. Vet. Med. Sci. 67 (11), 1103-1107.

Lespine A., Martin S., Dupuy J., Roulet A., Pineau T., Orłowski S., Alvinerie M. 2007. Interaction of macrocyclic lactones with P-glycoprotein: structure-affinity relationship. Eur. J. Pharm. Sci. 30(1), 84-94.

Lin L., Faraco J., Li R., Kadotani H., Rogers W., Qiu X., Jong P.J.D., Nishino S. 2004. The sleep disorder canine narcolepsy is caused by a mutation in the hypocretin (orexin) receptor 2 gene. Cell 98, 365-376.

Lohi H., Young E.J., Fitzmaurice S.N., Rusbridge C., Chan E.M., Vervoort M., Turnbull J., Zhao X.C. 2005. Expanded repeat in canine epilepsy. Science 307(5706), 81.

Mealey K. 2012. MDR1 Mutation. http://research.vet.upenn.edu/desktopmodules/penngenlabsearch/ /diseasefiles/80.pdf, access: 3.04.2016.

Mealey K.L., Fidel J., Gay J.M., Bergman P.J. 2008. ABCB1-1 delta polymorphism can predict hematologic toxicity in dogs treated with vincristine. J. Vet. Med. 22(4), 996-1000.

Michael B., Meinke P.T., Shoop W. 2001. Comparision of ivermectin, doramectin, selamectin and eleven intermediates in a nematode larval development assay. J. Parasitol. 87(3), 692-696.

Mizukami K., Chang H.S., Yabuki A., Kawamichi T., Hossain M.A., Rahman M.M., Uddin M.M., Yamato O. 2012. Rapid genotyping assays for the 4-base pair deletion of canine MDR1/ABCB1 gene and low frequency of the mutant allele in Border Collie dogs. J. Vet. Diagn. Invest. 24(1), 127-34. DOI: 10.1177/1040638711425591.

Mizukami K., Yabuki A., Chang H.S., Uddin M.M., Rahman M.M., Kushida K., Kohyama M., Yamato O. 2013. HPC Disease Markers 35(6), 669-672.

Monobe M.M., Araujo J.P. Jr, Kari V., Lunsford K.V., Rodrigo C., Silva R.C., Bulla C. 2015. Frequency of the MDR1 mutant allele associated with multidrug sensitivity in dogs from Brazil. J. Vet. Med., Research and Reports, 6, 111-117.

Panczyk M., Sałagacka A., Mirowski M. 2007. Gen MDR1 (ABCB1) kodujący glikoproteiną P z rodziny transporterów błonowych $A B C$, znaczenie w terapii i rozwoju nowotworów [MDR1 (ABCB1) gene encoding glycoprotein $P$ (P-gp), a member of $A B C$ transporter superfamily: consequences for therapy and progression of neoplastic diseases]. Post. Bioch. 53, 361-373. [in Polish]

Parton K.H. 2009 Abamectin toxicity in farm dogs. New Zealand Vet. J. 57, 69.

Patterson D. 2000. Companion animal medicine in the age of medicinal genetics. J. Vet. Internal. Med. 14, 1-9.

Pulliam J.D., Seward R.L., Henry R.T., Steinberg S.A. 1985. Investigation ivermectin toxicity in collies. Vet. Med. 80, 33-40.

Räber H. 1999. Encyklopedia psów rasowych II. Warszawa, Oficyna Wydaw. „Multico”, 200-386. [in Polish] 
Roberston K.R., Aaron K., Noa Safra. 2004. Breed distribution and history of canine mdr1-1 $\Delta$, a pharmacogenetic mutation that marks the emergence of breeds from the collie lineage. University of Washington, 11725-11730. DOI: 10.1073/pnas.0402374101.

Roliński Z. 2008. Farmakologia i farmakoterapia weterynaryjna. Warszawa, PWRiL, 23-74. [in Polish]

Rossenberg M., Callaghan R., Modok S. 2005. Three-dimensional structure of P-glycoprotein: the transmembrane regions adopt an asymmetric configuration in the nucleotide-bound state. J. Biol. Chem. 28, 280(4), 2857-2862.

Roulet A., Puel O., Gesta S., Lepage J.F. 2003. MDR1 deficient genotype in Collie dogs hypersensitive to the P-glycoprotein substrate ivermectin. Eur. J. Pharmacol. 24, 460(2-3), 85-91.

Sade H., Baumgartner C., Hugenmatter A., Moessner E. 2014. A human blood-brain barierr antibody transcytosis assays reveals antibody transcitosis influenced by $\mathrm{pH}$-dependent receptor binding. PIOs One 30, 9(4). DOI: 10.1371.

Sargan D. 2004. IDID:Inherited diseases in dog: Web-based information for canine inherited disease genetics. Mamm. Genome. 15(6), 503-506.

Sator L.L., Bentjen S.A., Mealey K.L. 2004. Loperamide toxicity in a collie with the MDR1 mutation associated with ivermectin sensitivity. J. Vet. Intern. Med. 18(1), 117-118.

Schinkel A.H., Smit J.J. 1994. Disruption of the mouse mdr1a P-glycoprotein gene leads to a deficiency in the blood-brain barrier and to increased sensitivity to drugs. Cell 20, 77(4), 491-502.

Schinkel A.H., Wagenaar E. 1996. P-glycoprotein in the blood-brain barrier of mice influences the brain penetration and pharmacological activity of many drugs. J. Clin. Invest. 97, 2517-2524.

Snowden N.J., Helyar C.V., Penderis J. 2006. Clinical presentation and management of moxidectin toxicity in two dogs. J. Small Anim. Pract. 47(10), 620-624.

Suzuki H., Sugiyama Y., Hirohashi T. 2000. Function and expression of multidrug resistance-associated protein family in human colon adenocarcinoma cells (Caco-2). J. Pharmacol. Exp. Ther. 292(1), 265-270.

Tabe Y., Konopleva M., Contractor R., Munsell M., Schoweb W.D. 2006. Up-regulation of MDR1 and induction of doxorubicin resistance by histone deacetylase inhibitor depsipeptide (FK228) and ATRA in acute promyelocytic leukemia cells. Blood 15, 107(4), 1546-1554.

Taylor N. 2011. The MDR1 gene, its story and its significance in collies, www.ovg.co.uk/MDR1.html, access: 3.04.2016.

Turner M.J., Schaeffer J.M. 1989. Mode of action of Ivermectin, in: Ivermectin and Abamectin. New York, Springer, 73-88.

Watanabe M., Maemura K., Kanbara K. 2002. GABA and GABA receptors in the central nervous system and other organs. Int. Rev. Cytol. 213, 1-247.

Wolstenholme A.J., Rogers A.T. 2005. An ivermectin-sensitive glutamate-gated chloride channel from the parasitic nematode Haemonchus contortus. Mol Pharmacol. 75 (6), 1347-1355.

Yas-Natan E., Shamir M., Kleinbart S. 2003. Doramectin toxicity in a collie. Vet. Record 6, 153(23), 718-720.

Abstract. Ivermectin is a drug used to fight endo- and exoparasites in animals at regular base in veterinary practice. Basically this substance is safe for mammals. The mechanism of its action is based on dysfunction of nerve impulses conduction. P-glycoprotein is a membrane transport protein present in endothelial cells of lungs, kidneys, liver and pancreas. It prevents toxin penetration into the brain neurons and many other organs outside central nervous system including barriers: blood-testis, blood-placenta, blood-urine. This protein is coded by Multi Drug Resistance gene 1 (MDR1 gene) and is located in membranes of blood-brain barrier cells. When a mutation in MDR1 gene appears the protein isn't able to function properly. In that case ivermectin goes to canine central nervous system cells and induces neurotoxic clinical signs, that is why early diagnostic is very important especially to prevent poisoning. The reasons and effects of the mutation as well as elements of molecular diagnostic that allows to identify the mutation were describe in this manuscript. Moreover, medicines that can induce neurotoxic signs in dogs with mutation in MDR1 gene were listed. 
